Annales Missiologici Posnanienses t. 25 (2020), s. 133-145

doi: $10.14746 / \mathrm{amp} .2020 .25 .9$

ORCID: 0000-0003-0793-4554

JĘDRZEJ MACHALSKI

Uniwersytet Adama Mickiewicza w Poznaniu

Wydział Teologiczny

\title{
Działalność Zgromadzenia Sióstr Służebniczek Najświętszej Maryi Panny Niepokalanie Poczętej jako realizacja misyjnego posłannictwa Kościoła
}

\section{Misyjny charakter Kościoła}

Zapisane w Dziejach Apostolskich słowa: „my nie możemy nie mówić tego, cośmy widzieli i słyszeli” (Dz 4,20), wygłoszone przed Sanhedrynem przez apostołów Piotra i Jana, wyrażają ich niezachwianą wiarę i świadomość misji powierzonej im przez Jezusa Chrystusa. Od czasów apostolskich Kościół nieprzerwanie odpowiada na Jego wezwanie: „Idźcie na cały świat i głoście Ewangelię wszelkiemu stworzeniu!” (Mk 16,15). Sobór Watykański II przypomniał, że posłuszeństwo temu poleceniu nie jest dla Kościoła jedną z dróg, ale jest jego niezbędnym zadaniem, ponieważ Kościół „z natury swojej jest misyjny" (DM 948). Papież Paweł VI w Adhortacji apostolskiej Evangelii nuntiandi pisał: „obowiązek ewangelizacji należy uważać za łaskę i właściwe powołanie Kościoła; wyraża on najprawdziwszą jego właściwość. Kościół jest dla ewangelizacji” (EN 13). Również Jan Paweł II podkreślał, że

misja Chrystusa Odkupiciela, powierzona Kościołowi, nie została jeszcze bynajmniej wypełniona do końca [oraz że] gdy obejmujemy spojrzeniem ludzkość, przekonujemy się, że misja Kościoła dopiero się rozpoczyna i że w jej służbie musimy zaangażować wszystkie nasze siły (RMis 249).

W nauczaniu papieża Franciszka od początku jego pontyfikatu często można znaleźć wypowiedzi świadczące o głębokiej u niego świadomości misyjnej natury Kościoła. W Orędziu na Światowy Dzień Młodzieży w 2013 r. pisał: „Głoszenie Ewangelii jest nieodłączne od faktu bycia uczniem Chrystu- 
sa i zakłada nieustanne zaangażowanie, które podtrzymuje całe życie Kościoła. 'Misyjny zapał jest wyraźnym znakiem dojrzałości wspólnoty kościelnej'” (ŚDM 2013). W pierwszych miesiącach pontyfikatu papieża Franciszka ukazała się encyklika Lumen fidei. Odnosząc się w niej do misyjnej tożsamości Kościoła, papież stwierdzał: „Ten, kto się otworzył na miłość Boga, usłyszał Jego głos i otrzymał Jego światło, nie może zatrzymać tego daru dla siebie” (LF 37). Jednakże najważniejszym dokumentem papieża Franciszka, w którym daje on wyraz swojej trosce o charakter misyjny Kościoła jest Adhortacja apostolska Evangelii gaudium o głoszeniu Ewangelii w dzisiejszym świecie (z listopada 2013 r.). Papież podkreślał, że wiarygodne głoszenie Ewangelii może odbywać się jedynie dzięki wcześniejszemu, osobistemu spotkaniu z Jezusem Chrystusem: „Każdy chrześcijanin jest misjonarzem w takiej mierze, w jakiej spotkał się z miłością Boga w Chrystusie Jezusie. Nie mówmy już więcej, że jesteśmy 'uczniami' i 'misjonarzami', ale zawsze, że jesteśmy 'uczniami-misjonarzami"” (EG 120). Ze spotkania z żywym Bogiem pochodzą: radość, entuzjazm i pasja, jak również: cierpliwość, wyrazistość, otwartość i zaangażowanie konieczne do owocnego głoszenia Ewangelii (EG 2,5,10,24). Z orędzi papieża Franciszka wygłaszanych z okazji Światowego Dnia Misyjnego, wśród odniesień do nauczania soborowego oraz do nauczania ostatnich papieży o misyjnej naturze Kościoła, przebija jego nowatorski sposób rozumienia tego, czym są misje we współczesnym świecie. W soborowym dekrecie poświęconym działalności misyjnej ad gentes misje utożsamiane są z konkretnymi obszarami geograficznymi. W wydanej dwadzieścia pięć lat później encyklice Redemptoris missio mówi się już o sytuacjach i środowiskach misyjnych. Zmiany zachodzące w świecie, zwłaszcza w społeczeństwie europejskim, owocujące sekularyzmem i obojętnością religijną, skłoniły papieża Franciszka do rezygnacji z rozumienia misji w sensie geograficznym i do wprowadzenia pojęcia: poszerzanie granic wiary (Szyszka 140-167). Trzecie Orędzie papieża Franciszka na Dzień Misyjny (w 2015 r.) przypadło na Rok Życia Konsekrowanego, dlatego papież poświęcił dużo uwagi zadaniom o charakterze misyjnym, jakie powinni podejmować zakonnicy i zakonnice. Pisał: „wymiar misyjny, należący do samej natury Kościoła, 'jest wpisany także w każdą formę życia konsekrowanego', a kiedy jest zaniedbywany, pozostawia pustkę, która zniekształca charyzmat". Tak papież przypomniał, że osoby konsekrowane w sposób szczególny związane są z działalnością misyjną Kościoła, a bagatelizowanie tego wymiaru nie tylko zaprzecza ich tożsamości, ale i podważa ich wiarygodność jako świadków Ewangelii:

wszelkie próby uchylenia się od tego powołania, nawet jeśli towarzyszą temu szlachetne motywacje związane z licznymi potrzebami duszpasterskimi, eklezjal- 
nymi lub humanitarnymi są niezgodne z indywidualnym powołaniem przez Pana do służby Ewangelii (ŚDM 2015).

Od czasów apostolskich i działalności św. Pawła (Zwilnian-Grabowski 7-21), pierwszego misjonarza, Kościół nieprzerwanie realizował powierzoną mu przez Jezusa Chrystusa misję niesienia Ewangelii wszystkim narodom. Głosił Dobrą Nowinę w Cesarstwie Rzymskim i poza jego granicami. Z grona tych, którzy szczególnie przyczynili się do rozkrzewienia wiary należy wymienić: św. Seweryna, mnichów irlandzkich, św. Willibrorda we Fryzji, apostoła Germanii św. Bonifacego, misjonarzy działających wśród arian, Wikingów, Słowian czy Węgrów, a także św. Franciszka z Asyżu, który stał się niejako odnowicielem ducha misyjnego. Wielkie odkrycia geograficzne w Indiach i Ameryce otworzyły przed Kościołem nieznane obszary dla działalności misyjnej. Troska o chrystianizację nowo odkrytych terenów znalazła swój wyraz m.in. w nauczaniu Magisterium Kościoła jak i w świadomości wiernych, zwłaszcza osób konsekrowanych, którzy zdecydowali się wyjechać, by głosić Ewangelię tam, gdzie jeszcze jej nie słyszano. Jednymi z pierwszych misjonarzy na terenach Nowego Świata byli franciszkanie i jezuici, których Chrystusowy nakaz misyjny zaprowadził, z upływem czasu, również do Chin. Obecnie działalności misyjnej poświęcają się osoby konsekrowane z kilkudziesięciu zgromadzeń. Wśród nich są także służebniczki ze zgromadzenia założonego przez bł. Edmunda Bojanowskiego, choć początkowo ich celem nie była praca na terenach misyjnych. Jednakże prześledzenie biografii (Tadrzak-Mazurek) założyciela oraz historii samego zgromadzenia uzmysławia głęboką świadomość misyjną E. Bojanowskiego i samych sióstr.

\section{Świadomość misyjnego posłannictwa Kościoła w życiu bł. Edmunda Bojanowskiego i działalności Zgromadzenia Sióstr Służebniczek}

Edmund Bojanowski urodził się w dniu 14 listopada 1814 r. w wielkopolskiej wsi Grabonóg, odległej około $3 \mathrm{~km}$ od Gostynia. W wieku czterech lat doznał cudownego uzdrowienia z ciężkiej choroby, o czym matka wielokrotnie mu opowiadała. Edmund nie uczęszczał do szkoły. Początkowo uczyła go matka, później pobierał prywatne lekcje w domu. Z tamtego czasu zachowały się wspomnienia jego rówieśników, którzy zapamiętali go jako dobrego człowieka o wrażliwym sercu. W 1832 r. wyjechał jako osiemnastoletni młodzieniec do Wrocławia, by studiować na uniwersytecie w stolicy Dolnego Śląska. Ciężkim doświadczeniem w czasie studiów okazała się dla niego śmierć matki (w 1934 r.) oraz - półtora roku później - śmierć ojca. Po tym ostatnim wy- 
darzeniu Edmund udał się do Berlina, gdzie zapisał się na studia na Wydziale Filozoficznym tamtejszego uniwersytetu. Dość szybko gruźlica zmusiła go do przerwania studiów. W 1838 r. opuścił Uniwersytet i po kuracji wrócił do rodzinnego Grabonoga (Tadrzak-Mazurek 59). Na tyle, na ile pozwalało mu zdrowie, E. Bojanowski włączył się w moralne i kulturalne odnowienie narodu polskiego, zwracając szczególną uwagę na ludzi z najuboższych warstw społecznych. Zakładał czytelnie wiejskie, organizował fundusze stypendialne dla biednej, ale zdolnej młodzieży, troszczył się o chorych i ubogich oraz bronił praw ludności polskiej, zamieszkującej ziemie zagarnięte przez zaborców. Był współtwórcą ochronek dla dzieci niechodzących jeszcze do szkoły. Szczególną wdzięczność zaskarbił sobie u ludzi podczas epidemii cholery, która nawiedziła Gostyń i okolice w 1849 r. Sam będąc słabego zdrowia, pielęgnował chorych, uzyskawszy dzięki temu miano: „drugi Wincenty a Paulo”. Epidemia pozostawiła po sobie wiele sierot. Zamierzając otoczyć je opieką, E. Bojanowski założył Dom Miłosierdzia, prowadzony przez siostry szarytki; chciał zapewnić dzieciom jak najlepsze warunki rozwoju i przygotować je do uczciwego, samodzielnego życia (Tadrzak-Mazurek 76-78). Dzień założenia pierwszej ochronki dla dzieci wiejskich w Podrzeczu (3 V 1850 r.) uznaje się za początek istnienia Zgromadzenia Sióstr Służebniczek. Wkrótce do ochronki zaczęły zgłaszać się coraz liczniej dziewczęta gotowe do końca życia pracować na rzecz dzieci, ubogich i chorych. Równocześnie z różnych miejsc zgłaszały się osoby, prosząc o założenie kolejnej ochronki. To doprowadziło do starań o otwarcie nowicjatu. Jednak zamiar założenia nowego zgromadzenia zakonnego zaczął budzić wątpliwości. Dziełu E. Bojanowskiego nie wróżono długiej przyszłości, ale mimo to, do zgromadzenia nieustanie zgłaszały się nowe kandydatki i wciąż napływały oferty zakładania kolejnych ochronek. Wkrótce nastąpiło zatwierdzenie ze strony Kościoła. Kiedy zgromadzenie rozwijało się, w E. Bojanowskim odezwało się silne pragnienie kapłaństwa. W dniu 30 marca 1869 r. wstąpił do Arcybiskupiego Seminarium Duchownego w Gnieźnie. Jednakże pogarszający się stan zdrowia już w maju 1870 r. zmusił go do przerwania formacji. Ostatnie miesiące życia spędził u jednego ze swoich przyjaciół - Stanisława Gieburowskiego, proboszcza w Górce Duchownej. Do końca swej doczesnej egzystencji interesował się sprawami sióstr, spotykał z nimi i korespondował (Tadrzak-Mazurek 129).

Zgromadzenie Sióstr Służebniczek w swoich założeniach nie zostało powołane do pracy na terenach misyjnych, niemniej jednak kolejne lata historii stopniowo odkrywały jego misyjny charakter. Zgromadzenie założone przez E. Bojanowskiego jeszcze za jego życia rozwijało się nie tylko w Wielkopolsce, ale także w Galicji, na Śląsku i w Królestwie Polskim. Wkrótce działalność sióstr spotkała się ze sprzeciwem zaborców. Ceną ocalenia placówek przed kasatą był podział zgromadzenia. W ciągu kilku następnych lat stopnio- 
wo wyodrębniły się jego cztery gałęzie: służebniczki wielkopolskie (z domem generalnym w Luboniu koło Poznania), starowiejskie (z domem w Starej Wsi koło Brzozowa), dębickie (w Dębicy) i śląskie (we Wrocławiu). Edmund Bojanowski uwrażliwiał siostry, by z posługą miłości spieszyły wszędzie tam, gdzie istnieje potrzeba. $\mathrm{Z}$ czasem zgromadzenie rozwijało się; zakładano nowe placówki, które swoim zasięgiem zaczęły obejmować kolejne części podzielonej Polski. Jeszcze za życia E. Bojanowskiego służebniczki starowiejskie podjęły pracę na terenach położonych poza granicami zaborów. Najwcześniej, w dniu 31 listopada 1861 r., założono pierwszą ochronkę w Galicji. Niedługo po otwarciu placówki zaczęły zgłaszać się kandydatki do życia zakonnego, dlatego po niecałym roku został otwarty nowicjat. Mimo licznych sprzeciwów ze strony władz państw zaborczych zgromadzenie rozwijało się dynamicznie, poszerzając obszar swego oddziaływania. Te i podobne działania moga świadczyć o obecnej w E. Bojanowskim, jak i w samych siostrach, głębokiej świadomości misyjnego posłannictwa Kościoła. Z biegiem lat świadomość ta kazała siostrom opuścić ojczyznę (Tadrzak-Mazurek 142-157).

\section{Afryka - pierwsze służebniczki poza granicami Polski}

Pierwszymi, które rozpoczęły pracę misyjną poza granicami Polski, były służebniczki starowiejskie. Na Czarnym Lądzie poświęcają one swoje życie służbie Ewangelii już od 1928 r. (Z historii). W 1913 r. jezuita Apoloniusz Kraupa, wyjeżdżając do Rodezji Północnej, zabrał z grobu swojej rodzonej siostry, służebniczki Karoliny, ziemię, by rozrzucić ją w Afryce. Siostra Karolina zmarła na gruźlicę w wieku zaledwie osiemnastu lat. Ojciec Apoloniusz nadał zabranej ziemi symboliczne znacznie zasiewu nowych służebniczekmisjonarek. Bóg spełnił jego pragnienie, lecz nie pozwolił mu tego doczekać. Po śmierci o. Apoloniusza pracujący na misjach polscy jezuici poprosili o przysłanie sióstr. Na tę prośbę chętnie odpowiedziało wiele ochotniczek. W 1928 r. na Czarny Ląd wyruszyły dwie grupy. Pierwsze cztery siostry wyjechały w dniu 24 kwietnia, a w dniu 5 grudnia udała się ich śladem druga grupa, tym razem trójosobowa. Pierwszym miejscem, w którym służebniczki starowiejskie podjęły pracę (w 1928 r.) było Chingombe, misja ufundowana przez Teresę Ledóchowską. Rok po przyjeździe siostry założyły tam internat i szkołę dla dziewcząt. Dorosłych i dzieci uczyły czytania, pisania, rachunków i śpiewu. W 1938 r. rozpoczęły nauczanie chłopców w szkole centralnej. By móc lepiej porozumiewać się uczyły języka angielskiego, ponieważ miejscowa ludność mówiła wówczas w dziesięciu dialektach. Misjonarki opiekowały się także chorymi i troszczyły o kościół misyjny. Drugą miejscowością, w której siostry podjęły pracę było Kasisi. W styczniu 1929 r. przejęły tam dom 
po dominikankach i zgodnie z charyzmatem zgromadzenia zajęły się przede wszystkim dziećmi. Prowadziły szkołę i mały internat, nie zaniedbując chorych i potrzebujących, którzy mieszkali poza miejscowością. Z upływem czasu dom rozbudowano, przeznaczając jego część specjalnie dla sierot. Powstała też oddzielna placówka zajmująca się nauczaniem dzieci. Od 1939 r. siostry działały również w Katondwe, prowadząc szpital, kuchnię, szwalnię i nauczając dzieci. W 1948 r. w RPA erygowano dom zakonny i nowicjat, a w 1954 r. w ówczesnej Rodezji Północnej otwarto nowicjat dla powołań tubylczych. W 1959 r. jezuici otworzyli w Matero szkołę podstawową dla dziewcząt, prosząc, by siostry podjęły w niej pracę. W roku 1968 na terenie Afryki erygowana została prowincja Zgromadzenia Sióstr Służebniczek. Po roku liczba rodowitych sióstr Afrykanek przewyższyła liczbę polskich misjonarek ( $Z$ historii).

Obecnie w Zambii istnieje 25 placówek, w których siostry z Polski pracują razem z siostrami Zambijkami. W Malawi działają trzy domy, gdzie posługują siostry Zambijki, dwa domy w Tanzanii, w których pracują siostry z Afryki, oraz cztery domy w RPA. Siostry prowadzą ogółem 22 przedszkola z 2262 dziećmi, 10 szkół podstawowych z 8169 uczniami i szkoły średnie z internatami w Zambii, z 2468 uczniami. Ponadto posługują chorym w kilkudziesięciu przychodniach i szpitalach, ale także dojeżdżają do wiosek. Prowadzą programy lecznicze i profilaktyczne, by podnosić świadomość zdrowotną tamtejszej ludności. Przy szpitalach organizują praktyki i szkoły pielęgniarskie. Pracują charytatywnie, parafialnie i duszpastersko. Poza Afryką służebniczki dębickie są również zaangażowane w działalność misyjną na Jamajce, gdzie oddają się pracy nauczycielskiej, wychowawczej i ewangelizacyjnej. W Rosji prowadzą trzy przedszkola, świetlice oraz pomagają bezdomnym i rodzinom, podobnie na Ukrainie i w Mołdawii (Z historii).

\section{Działalność misyjna Sióstr Służebniczek Niepokalanego Poczęcia NMP}

Działalności misyjnej poświęciły się siostry każdej z tworzących Federację gałęzi. Służebniczki Niepokalanego Poczęcia NMP, zwane wielkopolskimi, których Dom Generalny znajduje się w Luboniu, pracują w Kazachstanie, na Białorusi, w Brazylii, a także we Włoszech i w Szwecji. W Kazachstanie, pod koniec lat osiemdziesiątych ubiegłego wieku, władze moskiewskie zaczęły wydawać pozwolenia na budowę świątyń. Na początku 1990 r. takie pozwolenie otrzymali też mieszkańcy Oziornoje. Równocześnie zwrócili się z prośbą do prymasa Polski, wówczas kardynała Józefa Glempa, o przysłanie do Oziornoje kapłana. Podobne prośby złożyli również polscy zesłańcy z Szortand i Czkałowa. Jednym z kapłanów, którzy zgodzili się tam pojechać był Tadeusz Krzymiński. To właśnie na jego prośbę trafiły do Kazachstanu 
pod koniec 1990 r. trzy siostry z Lubonia, ponieważ, jak twierdził T. Krzymiński, w Kazachstanie panują podobne warunki, z jakimi musiał mierzyć się E. Bojanowski, gdy zakładał ochronki dla dzieci i inicjował zgromadzenie. Także w Kazachstanie odrodzenie społeczeństwa, wiary i ducha narodowego należało zacząć od dzieci i młodzieży. W 1993 r. siostry dotarły do Czkałowa, a w parafii w Oziornoje pierwsze służebniczki rozpoczęły swoją misję w dniu 7 sierpnia 1994 r. (Misje).

Dzisiaj siostry pracują w czterech miejscach w Kazachstanie. Prowadzą trzy domy na północy kraju i jeden na południu. Ich posługa polega głównie na pracy w ochronkach z dziećmi. Służebniczki opiekują się też chorymi i ubogimi nie tylko materialnie, ale i moralnie. Prowadzą katechezy dla dzieci i dorosłych oraz troszczą się o parafialne kościoły, służąc i modląc się przy parafii. Służebniczki w Kazachstanie współpracują z kapłanami, pomagając w prowadzeniu parafii, wyjeżdżają wraz z nimi do wiosek, aby tam katechizować i przygotowywać do przyjęcia sakramentów dzieci, młodzież i dorosłych. W Oziornoje w dniach wolnych od nauki siostry organizują obozy dla dzieci z parafii i okolicznych wsi. W sierpniu włączają się w organizację trwającego przez cztery dni Święta Młodych, które od siedemnastu lat gromadzi młodzież z całego Kazachstanu i z innych państw. Na Białorusi siostry posługują w Indurze i, tak jak w Kazachstanie, zajmują się głównie katechizacją dzieci i młodzieży oraz troszczą się o chorych i potrzebujących. Do Brazylii służebniczki dotarły w dniu 11 lutego 1954 r. Obecnie podejmują pracę głównie wśród chorych, ale także, podobnie jak w pozostałych krajach, prowadzą ochronki, zajmują się katechizacją dzieci i młodzieży oraz włączają się w prace parafialne (Misje).

\section{Praca na misjach Sióstr Służebniczek NMP Niepokalanie Poczętej}

Służebniczki, nazywane śląskimi, poza granicami ojczyzny pracują w Kolonii, w Czechach, we Włoszech i Francji, na Ukrainie i Białorusi, w Kanadzie oraz w siedmiu miejscowościach w Kamerunie (Placówki). W Figuil, siedzibie administracyjnej Regionu Afrykańskiego, gdzie mieści się dom formacyjny kandydatury zgromadzenia, siostry prowadzą dwuoddziałowe przedszkole i Misyjny Ośrodek Zdrowia, w którym m.in. opiekują się chorymi na AIDS i niepełnosprawnymi. Udzielają się także w pracy pastoralnej, prowadząc katechezy w parafii i w okolicznych wioskach. Troszczą się o tamtejsze sanktuarium, posługując w zakrystii. Towarzyszą też Stowarzyszeniu Rodziny bł. Edmunda Bojanowskiego. W mieście Tcholliré prowadzą przedszkole, sierociniec, aptekę i, tak jak w Figuil, katechizują oraz zajmują się pracą z dziećmi i młodzieżą niepełnosprawną. W Mandamie prowadzą ochronkę 
dla dzieci, internat dla dziewcząt i katechizują w miejscowym gimnazjum. Włączają się również w opiekę nad ministrantami oraz innymi grupami młodzieżowymi i duszpasterskimi. Troszczą się o formację katechetów. Ponadto obsługują misyjną aptekę, a z posługą charytatywną i pastoralną dojeżdżają także do okolicznych wiosek. W placówce w Ngaoundéré mieści się ich nowicjat. W miejscowych szkołach siostry prowadzą katechezy oraz grupy duszpasterskie m.in. grupę biblijną i dzieci Cop'Monde. W jednej z miejscowości Kamerunu, w Mokolo, ludzie są nękani atakami bojowników Boko Haram. Dla bezpieczeństwa wspólnotę tworzą tam tylko siostry pochodzenia kameruńskiego. Administrują wioską dla Trędowatych Centrum Rohan - Chabot. Sprawują opiekę nad ośrodkiem zdrowia, prowadzą rehabilitację dla osób niepełnosprawnych, zapewniając im też wyżywienie, prowadzą przedszkole, pomagając również dzieciom i młodzieży szkolnej. Placówka w Yaounde jest domem dla studiujących sióstr. Oprócz studiowania siostry pracują w ośrodku zdrowia na porodówce. Opiekują się grupami duszpasterskimi i organizują niedziele powołaniowe, a także towarzyszą duchowo więźniom $\mathrm{z}$ więzienia centralnego. W ostatniej z kameruńskich placówek w Kombou służebniczki prowadzą dwuoddziałowe przedszkole, katechezy do bierzmowania, grupy liturgiczne i duszpasterskie oraz chór parafialny (Placówki). We wszystkich placówkach w Kamerunie towarzyszą duchowo Stowarzyszeniu Rodzina bł. Edmunda Bojanowskiego, które tworzą osoby świeckie, pragnące za wzorem swojego patrona jednoczyć się wokół dobra, w celu służenia ludziom potrzebującym pomocy, zwłaszcza dzieciom, chorym, osobom starszym i samotnym. Należący do Rodziny bł. Edmunda Bojanowskiego decydują się stale pogłębiać swoje życie chrześcijańskie przez zachowanie przykazań Bożych i zasad moralnych, tak by nieustannie wzrastać w doskonałości ewangelicznej, oraz dobrowolnie uczestniczyć w apostolsko-charytatywnych dziełach zgromadzenia, gdziekolwiek są one prowadzone, współpracując w nich ze służebniczkami (Założenia).

\section{Działalność misyjna Sióstr Służebniczek Bogarodzicy Dziewicy Niepo- kalanie Poczętej w Boliwii i Peru}

Służebniczki Bogarodzicy Dziewicy Niepokalanie Poczętej, dębickie, założyły placówki misyjne w Boliwii i w Peru. Praca w Boliwii jest szczególnie trudna ze względu na obecną tam, pełną kontrastów kulturę, zwłaszcza w przestrzeni, w której wiara chrześcijańska styka się z wciąż żywą tradycją i wierzeniami indiańskimi. Siostry rozpoczęły posługę w Boliwii w 1982 r. Obecnie prowadzą szkoły, przedszkola, ochronki i internat dla dzieci. Opiekują się także Domem Dziecka oraz kierują przychodnią dla chorych. Ponadto podej- 
mują pracę jako pielęgniarki w miejscowym szpitalu. Katechizują w szkołach i przy parafiach. Udzielają się w życiu parafialnym także jako zakrystianki, wspomagają też miejscowych księży w działaniach duszpasterskich. Ponadto posługują biednym i ubogim w boliwijskich wioskach (Działalność misyjna Zgromadzenia Stużebniczek).

Od 2012 r. służebniczki oddają się pracy misyjnej również w Peru. W najbardziej wysuniętym na południe, leżącym przy granicy mieście Tacna troszczą się o dzieci z ochronki parafialnej, katechizują w miejscowej szkole oraz prowadzą Centrum Terapii dla dzieci z upośledzeniem. Podobnie jak w innych placówkach, w różnorodny sposób są obecne też w duszpasterstwie parafialnym (Działalność misyjna Zgromadzenia Stużebniczek). Niezwykle cennym świadectwem pracy misyjnej służebniczek stał się film wyreżyserowany przez braci Syka, którego premiera miała miejsce w Internecie w Wielkanoc (,niedziela Zmartwychwstania") w 2020 r. Film powstawał ponad trzy lata. Opowiada o posłudze służebniczek, które kontynuując misję swojego założyciela i patrona bł. E. Bojanowskiego, pomagają chorym i cierpiącym, szczególną pieczą otaczając dzieci. Premiera filmu zbiegła się z przybierającą na sile epidemią (koronawirus), wpisując się swoją tematyką i przesłaniem w panującą wówczas w Polsce i na świecie atmosferę. Film przybliża historie sióstr, które codziennie, podobnie jak ich patron, niosą ukojenie ofiarom przeróżnych epidemii i chorób (Maciej Syka). Wiosenne miesiące postawiły siostry przed niemałym wyzwaniem: zmierzenia się z kolejną z nich. Dotkliwie odczuły to siostry z Boliwii. Prowadzony przez nie szpital przeznaczono dla chorych na covid-19. Wiele dzieci znajdujących się pod opieką sióstr w domach dziecka czy ochronkach, z powodu warunków, w jakich żyją, jest słabego zdrowia, co wystawiło je na szczególne niebezpieczeństwo. Licznych trudności przysporzyły także obostrzenia dotyczące uczęszczania dzieci do szkół, ponieważ w związku z zawieszeniem zajęć wszystkie lekcje musiały być prowadzone w ośrodkach. W Domu Dziecka w Tarija siostrom pomagały dwie wolontariuszki, które przebywają tam od ubiegłego roku. Prowadziły lekcje, organizowały konkursy, przygotowywały przedstawienia i rozmaite imprezy, np. urodziny dzieci, Dzień Dziecka czy uroczystości religijne. Dzieciom pozostającym przez cały dzień na miejscu trzeba było również zapełnić czas wolny. Uczące religii siostry organizowały lekcje i spotkania na różnych platformach, by $\mathrm{w}$ ten sposób nadal uczyć, ale przede wszystkim, by dodawać nadziei. W parafii w Cochabamba nie odprawiano Mszy Świętej, ponieważ ze względu na brak plebanii proboszcz nie mógł przebywać na terenie parafii. Siostry uczestniczyły we Mszy Świętej w domowej kaplicy dzięki transmisjom on-line. Dla wiernych przez kościelne głośniki prowadziły codziennie różaniec i Koronkę do Bożego miłosierdzia. Parafianie mogli telefonicznie zgłaszać intencje odczytywane następnie podczas wspólnej modlitwy. Z powodu epidemii 
biedniejszym rodzinom jeszcze bardziej zaczęło brakować żywności. Siostry postanowiły więc zadbać o to, by, poza dostarczaniem pokarmu duchowego, zaspokajać ich codzienne potrzeby (Życzenia świąteczne). W dniu 17 marca 2020 r. zamknięto także szkoły i przedszkola prowadzone przez służebniczki w Kamerunie. Na północy kraju postanowiły one zorganizować w wioskach spotkania edukacyjne o postępowaniu w czasie epidemii. Jednakże odwołano wszystkie spotkania. Jednym z poważniejszych wyzwań było, ze względu na panujące warunki, wprowadzenie w życie zasad higieny i używania np. środków do dezynfekcji, których brakowało nawet w szpitalach, nie mówiąc już o przeznaczonych do codziennego użytku. Wkrótce po wybuchu epidemii w niektórych regionach Kamerunu dało się wyczuć narastającą niechęć do Europejczyków. Rdzenni mieszkańcy zaczęli obarczać ich winą za pojawienie się wirusa w Kamerunie. Nie bez powodu. Zarażeni, których zdiagnozowano najpierw w stolicy Yaoundé, następnie w Douala, a później w innych dużych miastach, byli obcokrajowcami. W pierwszych tygodniach epidemii wspólnoty w Kombou i Yaoundé poddane zostały kwarantannie. Siostry w Yaoundé mogły uczestniczyć w codziennej Eucharystii tylko dzięki transmisjom, mając jednak możliwość przyjęcia Komunii świętej w kaplicy domowej (Życzenia świateczne). Z podobnymi problemami musiały zmierzyć się służebniczki w pozostałych częściach świata.

\section{Wspieranie dzialalności misyjnej - realizacją Chrystusowego nakazu}

Do publikowanych w Internecie życzeń wielkanocnych siostry często dołączały prośbę o modlitwę i wsparcie. $Z$ powodu epidemii niemożliwe stały się wyjazdy wolontariuszy, którzy co roku zasilali szeregi pracujących poza granicami misjonarzy. Okazało się jednak, że ten czas zaowocował ogromnym wzrostem zachowań altruistycznych i filantropijnych. W przeróżne formy pomagania innym włączało się coraz więcej osób mających do tej pory może niewielkie doświadczenie, ale za to mnóstwo dobrej woli. Chętni łączyli się w grupy, zakładali fundacje, organizowali zbiórki. Włączając się w tego rodzaju wsparcie dla misji, zapewniali nie tylko konkretną pomoc samym misjonarzom, ale i osobom w swoim otoczeniu, dawszy dowody troski o Kościół w jego powszechności, zgodnie ze słowami Apostoła Narodów:

Podobnie jak jedno jest ciało, choć składa się z wielu członków, a wszystkie członki ciała, mimo iż są liczne, stanowią jedno ciało, tak też jest i z Chrystusem. [...] Tak więc, gdy cierpi jeden członek, współcierpią wszystkie inne członki; podobnie, gdy jednemu członkowi okazywane jest poszanowanie, współweselą się wszystkie członki. Wy przeto jesteście Ciałem Chrystusa i poszczególnymi członkami (1 Kor 12,12;26n). 
Istnieje wiele sposobów wspierania służebniczek pracujących na misjach, jak choćby adopcja serca, czyli opieka duchowa i materialna nad dzieckiem z kraju misyjnego. Osoba, która zdecyduje się na tego rodzaju wsparcie, modli się $\mathrm{w}$ intencji tego dziecka i systematycznie wspiera materialnie, pomagając w jego utrzymaniu. Podobną formą pomocy jest tzw. patronat misyjny. Jest to również opieka duchowa i materialna, ale sprawowana nad konkretnym misjonarzem czy konkretną placówką misyjną, lub wspieranie formacji misyjnej poprzez włączenie się w utrzymanie postulatu i nowicjatu dla miejscowych powołań. Na stronie internetowej Zgromadzenia Sióstr Służebniczek Najświętszej Maryi Panny Niepokalanie Poczętej siostry informują o aktualnych potrzebach i działaniach, które można wesprzeć (Pomoc misjom). Czy taka pomoc nie będzie realizacją wezwania, które skierował do nas papież Franciszek w Orędziu na Światowy Dzień Misyjny w 2013 r., by wychodzić na peryferie? (ŚDM 2013). Należy przy tym pamiętać o następujących słowach Jezusa Chrystusa: „Zaprawdę, powiadam wam: Wszystko, co uczyniliście jednemu z tych braci moich najmniejszych, Mnieście uczynili” (Mt 25,40).

\section{ACTIVITY OF THE CONGREGATION OF THE SISTERS SERVANTS OF THE HOLY AND IMMACULATE VIRGIN MARY AS A REALIZATION OF THE MISSIONARY CALLING OF THE CHURCH}

\section{Summary}

Since the apostolic times, the Church has continuously fulfilled the invitation addressed by Jesus to his disciples: Go ye into all the world, and preach the Gospel to every creature (Mark 16:15). The Second Vatican Council, writing about the missionary nature of the Church, clearly emphasized the importance of the task of bringing the Good News to all people on Earth. This mission includes the activity of the Sisters Servants of the Holy and Immaculate Virgin Mary, a congregation founded by blessed Edmund Bojanowski. Although the congregation was not established with missionary work in mind, the first Sisters left Poland as early as 1928, realizing the deep missionary awareness that had always been present in Bojanowski. Currently, the Sisters work almost on all continents, running schools and nurseries for children, serving the sick in clinics and hospitals, working for charity, parishes and pastoral care. The spring months faced the Sisters with the challenge of dealing with the covid-19 virus epidemic, which affected, among others, the functioning of the hospitals and schools run by the Sisters, putting many children in poor health at risk because of the conditions in which they live. The Sisters often added a request for prayer and support to the current news published on the Internet. Although due to the epidemic, the departures of volunteers became impossible, many people of good will supported and 
continue to support the missionary activity of the Sisters, remembering the words of Christ: Truly I say to you, to the extent that you did it to one of these brothers of Mine, even the least of them, you did it to Me (Matthew 25:40).

Keywords: Edmund Bojanowski; missionary awareness; missionaries; nurseries; children; Africa; Bolivia; Kazakhstan; covid-19

Słowa kluczowe: Edmund Bojanowski; świadomość misyjna; misjonarze; ochronki; dzieci; Afryka; Boliwia; Kazachstan; covid-19

\section{Wykaz skrótów}

DM - Sobór Watykański II. Dekret o działalności misyjnej Kościoła Ad gentes divinitus

EG - Franciszek. Encyklika Evangelii gaudium. Rzym 2013

EN - Paweł VI. Encyklika Evangelii nuntiandi. Rzym 1975

LF - Franciszek. Encyklika Lumen fidei. Rzym 2013

RMis - Jan Paweł II. Encyklika Redemptoris missio. Rzym 1990

ŚDM - Orędzie na Światowy Dzień Misyjny.

\section{BIBLIOGRAFIA}

Franciszek. Encyklika Lumen fidei. Kraków: WAM 2013, 37.

Franciszek. Adhortacja apostolska Evangelii gaudium. Wrocław: Wydawnictwo TUM, 2014.

Franciszek. Orędzie na Światowy Dzień Misyjny 2013. Dostęp 9 września 2020. <https://w2.vatican. $\mathrm{va} /$ content/francesco/pl/messages/missions/documents/papa-francesco_20130519_giornata-missionaria2013.html>

Franciszek. Orędzie na Światowy Dzień Misyjny 2015. Dostęp 7 sierpnia 2020. <www.misje.pl/aktualnosci/wydarzenia/15938/oredzie-papieza-franciszka-na-swiatowy-dzien-misyjny18-pazdziernika-2015-roku>

Jan Paweł II. Encyklika Redemptoris mission. 1: AAS 83 (1991), 249.

Maciej Syka. Dostęp 9 września 2020 r. <https://pl.aleteia.org/2020/01/22/maciej-syka-rezyseremfilmu-pewnosc-jest-duch-swiety-nie-ja-wywiad/>

Misje. Dostęp 9 września 2020. <http://www.siostry-maryi.pl/misje.html>

Paweł VI. Adhortacja apostolska. Evangelii nuntiandi. 14: AAS (1976), 13.

Placówki misyjne Zgromadzenia Sióstr Stużebniczek NMP Niepokalanie Poczętej. Dostęp 9 września 2020. <http://www.sluzebniczki.pl/placowki,s,sub11.html>

Pomoc misjom. Dostęp 9 września 2020. <http://www.sluzebniczkinmp.pl/misje-i-ewangelizacja-8712/pomoc-misjom-10143>

Sobór Watykański II. Dekret o misyjnej działalności Kościoła Ad gentes. 7: AAS 58 (1966), 948.

Szyszka, Tomasz. „Misyjne impulsy papieża Franciszka.” Nurt 2 (2016): 140-167.

Tadrzak-Mazurek, Małgorzata. Dobrodziej. Luboń: Zgromadzenie Sióstr Służebniczek Niepokalanego Poczęcia NMP, 2015.

Założenia Stowarzyszenia Rodzina bt. Edmunda Bojanowskiego. Dostęp 9 września 2020. <http:// www.sluzebniczki.pl/zalozenia,s,sub5.html> 
Z historii placówek misyjnych. Siostry Stużebniczki NMP Starowiejskie w stużbie Ewangelii w Afryce od 1928 roku. Dostęp 9 września 2020. <http://www.sluzebniczkinmp.pl/misje-iewangelizacja-8712/z-historii-placowek-misyjnych-10120\#1>

Z Kaтеrunu. Dostęp 9 września 2020. <http://www.sluzebniczki.pl/misje,s,sub11.html

Działalność misyjna Zgromadzenia Służebniczek. Dostęp 9.09.2020. https://siostry.net/misje/>

Zwilnian-Grabowski, Tadeusz. „Podróże misyjne świętego Pawła.” Colloquia Theologica Ottonia$n a \mathrm{nr} 2$ (2008): 7-21.

Życzenia świąteczne. Dostęp 9 września 2020. <http://www.sluzebniczki.pl/news,z_kamerunu, 2000.html>

JęDRZeJ MaChaLSKI, kapłan archidiecezji poznańskiej, doktorant na Wydziale Teologicznym UAM. 
